\title{
Relations between soil heterogeneity and common reed (Phragmites australis Trin. ex Steud.) colonization in the Keriya River Basin, Xinjiang of China
}

\author{
Lu GONG ${ }^{1,2 *}$, ChangJun $\mathrm{LI}^{1,3,4}$, Tashpolat TIYIP ${ }^{1,2}$ \\ ${ }^{1}$ College of Resources and Environment Science, Xinjiang University, Urumqi 830046, China; \\ ${ }^{2}$ Key Laboratory of Oasis Ecology, Ministry of Education, Urumqi 830046, China; \\ ${ }^{3}$ Xinjiang Institute of Ecology and Geography, Chinese Academy of Sciences, Urumqi 830011, China; \\ ${ }^{4}$ Cele National Station of Observation \& Research for Desert-Grassland Ecosystem in Xinjiang, Cele 848300, China
}

\begin{abstract}
How common reed (Phragmites australis Trin. ex Steud.) colonization correlates to soil heterogeneity and environmental determinants remains unclear in arid areas. We conducted a field investigation and soil sampling in 100 plots along Keriya River Basin to uncover the relationship between common reed and heterogeneous soils. Reed colonization variables and its soil properties were measured and recorded for the analysis of their relationship using Pearson correlation and redundancy analysis methods. The comparison results of common reed characteristics among 100 plots showed that common reeds performed strong tolerance and ecophysiological plasticity to edaphic stresses. Common reed colonization was tightly connected to soil heterogeneity according to the correlation analysis between its colonization characteristics and soil properties. Common reed colonization got feedbacks on soil properties as well, including the increase of soil organic matter and the alleviation of salt uplifting. The main limiting environmental determinant of common reed colonization was soil salt, followed by $\mathrm{pH}$ and soil water content.
\end{abstract}

Keywords: soil heterogeneity; plant colonization; common reed; plasticity; determinant

Citation: Lu GONG, ChangJun LI, Tashpolat TIYIP. 2014. Relations between soil heterogeneity and common reed (Phragmites australis Trin. ex Steud.) colonization in the Keriya River Basin, Xinjiang of China. Journal of Arid Land, 6(6): 753-761. doi: 10.1007/s40333-014-0031-7

In recent years, there is a raising awareness of the importance of plant-soil interactions among ecologists, especially in the context of plant spread and succession (Alpert, 2000; Ehrenfeld, 2005; Eppstein and Molofsky, 2007). Studies have demonstrated that spatial heterogeneity and resources availability influence plant growth, reproduction, plant community composition and diversity (Tilman and Wedin, 1991; Huston, 1993; Collins and Wein, 1998; Baer et al., 2004). Spatial difference of soil resources resulting from land cover presence and composition (Hook et al., 1991; Vinton and Burke, 1995), topography (Burke et al., 1999), soil animals or microbes activity (Bever et al., 1994) and soil disturbances (Robertson et al., 1993), will strongly affect plant existence, growth and reproduction (Bardget et al., 2005; Manning et al., 2008). Plants also have a negative or positive feedback on soil texture, chemical property and soil community (Ehrenfeld et al., 2005; Bardgett et al., 2009). Recent advances in ecological science have greatly contributed to our understanding of the soil-plant interaction which benefits to the restoration of ecosystem (Valerie and Christine, 2008), but experiences on the relationship between soil heterogeneity and plant colonization in arid natural system that contributes to vegetation restoration activities are still not much clear, and also this kind of experiences have been rarely known on common reed (Phragmites australis Trin.

*Corresponding author: Lu GONG (E-mail: gonglu721@163.com) 
ex Steud.) in arid areas, owing to its adaptability and existence in a wide range of ecosystem and soil types.

Common reed is a cosmopolitan species due to its long range of physiological plasticity and strong abiotic stress tolerance (Lisamarie and Richard, 1999; Majken et al., 2005; Vasquez et al., 2005). Vegetative reproduction via rhizomes and rapid recovery after disturbance to the aboveground growth enhanced its colonization ability (Meyerson et al., 2000), while strong abiotic stress tolerance helps to its succession in submerged brackish regions as well as non-flooded dry ones (Roberts, 2000; Thevs et al., 2007). Common reed colonization often leads to the decrease of other plant species and forms the near monoculture (Meyerson et al., 2000), but still it remains a controversy whether this kind of ecosystem evolution is a threat or a favor (Weis and Weis 2003; Marty et al., 2007). The rapid spread of common reed caused agriculture and ecosystem damages in some wetlands (Benoit and Askins, 1999; Chambers et al., 2003), but it delivers habitat and food values as well (Weis and Weis, 2003). However, as to those in arid areas, vegetation in desert edge showed its potentialities to alleviate sandstorm and floating dust (Qian et al., 2007), and common reed dominated in these areas (Li et al., 2010). Thus there should be a desiderating need to figure out how common reed reacts to soil heterogeneity and what are the determinants limiting common reed spread in arid areas.

Here, we took field sampling and experiments to show plastic variances of common reed and soil heterogeneity in reed growing plots in order to figure out the correlations between common reed and soil heterogeneity. Finally, the edaphic determinants on common reed inhabitation succession were selected for better understanding the soil limitation of common reed colonization.

\section{Materials and methods}

\subsection{Study area and field sampling}

Field investigation was carried out in a region along Keriya River Basin $\left(37^{\circ} 00^{\prime}-37^{\circ} 59^{\prime} \mathrm{N}, 81^{\circ} 14^{\prime}-81^{\circ} 38^{\prime} \mathrm{E}\right)$ in the southern fringe of the Taklamakan Desert, Xinjiang of China (Fig. 1). The climate here is extremely arid with the mean annual precipitation of $35.1 \mathrm{~mm}$ and potential evaporation more than $2,600 \mathrm{~mm}$. The

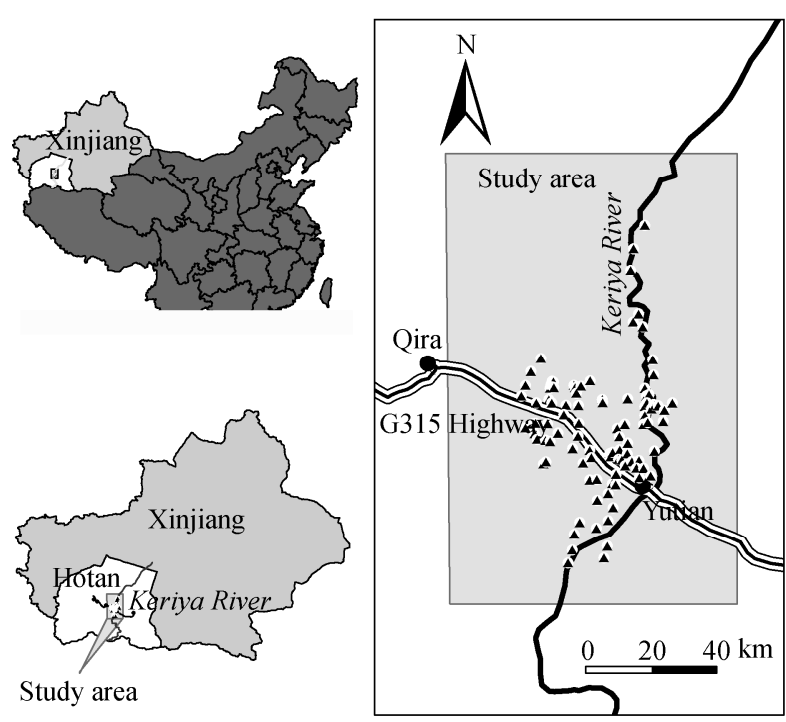

Fig. 1 Study area and sampling sites (triangles are sampling sites)

annual average temperature is $12.2^{\circ} \mathrm{C}$. The natural vegetation here is composed by xerophytes, primarily Alhagi sparsifolia Shap., Karelinia caspica (Pall.) Less., Scorzonera divaricata Turcz., Tamarix spp., Populus euphratica Oliv., Phragmites australis Trin. ex Steud. and Sophora alopecroides L. Soil water and salt contents, soil types and groundwater depths vary in different transects here (Li et al., 2010). Along with desertification reverse action and oasis construction in the study area, Phyragmites australis colonized and spread to deserts once bared or dominated by xerophytes.

The investigation was taken up at the end of the growing season (15 September-5 October 2012) for distinguishing the significant growth difference among heterogeneous soils. One hundred reed growing sites in this arid area were sampled. The minimum and maximum of the distance between each two sites were 0.306 and $111.31 \mathrm{~km}$, respectively. All individuals sampled in different sites were surely apart from each other. Basic growth variables like shoot quantity, height and relative coverage in each randomly chosen $1 \mathrm{~m} \times 1 \mathrm{~m}$ plot were measured and recorded. We harvested all the reed shoots and rhizomes to determine the biomass. Rhizomes and soil samples were collected from five soil layers $(0-10,10-30,30-60$, $60-100$ and $100-150 \mathrm{~cm}$ ) according to rhizome, soil water and salt distribution, homogenized and stored in 
sealed plastic bags and brought back for further experiments.

\subsection{Measurements of plant growth}

Shoot quantity (Q), shoot biomass, rhizome biomass, shoot mean height $(\mathrm{H})$, shoot maximum height (Hmax) and relative coverage $(\mathrm{C})$ were measured and recorded in each plot. All the biomass samples were dried in an oven for $48 \mathrm{~h}$ at $70^{\circ} \mathrm{C}$ for dry biomass (including shoot dry biomass (DBs) and rhizome dry biomass $(\mathrm{DBr}))$ determination. The rhizome/shoot ratio $(\mathrm{R} / \mathrm{S})$, shoot water content (WCs) and rhizome water content (WCr) were calculated for further study.

\subsection{Measurements of soil properties}

Soil samples collected from different soil layers were air-dried and sieved through a 2-mm screen for analyses. Soil properties including soil water content, salt content, $\mathrm{pH}$, organic matter, total nitrogen, available phosphorus, available potassium and ions concentrations were analyzed in the laboratory of Xinjiang Institute of Ecology and Geography, Chinese Academy of Sciences. Soil $\mathrm{pH}$ was determined using a $\mathrm{pH}$ meter (PH-2C pH meter, Shanghai Lida Apparatus Manufactory, China) with 1:5 soil/water ratio. In total dissolved salt content (called TDS below), soil $\mathrm{Na}^{+}$and $\mathrm{K}^{+}$were extracted by $1: 5 \mathrm{soil} /$ water ratio and analyzed with a flame photometer (Model 2655-00 Digital Flame Analyzer, Cole-Parmer Instrument Company, Chicago, IL). $\mathrm{Ca}^{2+}, \mathrm{Mg}^{2+}, \mathrm{Cl}^{-}, \mathrm{SO}_{4}{ }^{2-}, \mathrm{CO}_{3}{ }^{2-}$ and $\mathrm{HCO}_{3}{ }^{-}$were measured using 1:5 soil to water suspension by the same way according to Sonmez et al. (2008).

\subsection{Data analysis}

Pearson correlation method was chosen and done by SPSS 16.0 (Apache Software Foundation, Chicago, IL, USA) for determining the relationship between soil heterogeneous factors and common reed colonization variables. Unlike aquatic habitats, the rhizomes and roots of common reed we investigated were only found in the soils below $30 \mathrm{~cm}$, thus we only used the soil factors below $30 \mathrm{~cm}$ for correlation analysis. Multivariate statistics analysis of growth variables and environmental factors was employed by CANOCO 4.5 (Microcomputer Power, Ithaca, NY, USA). Since the Eigenvalues of Detrended Correspondence Analy- sis (DCA) on plant variables were all lower than 3, Redundancy Analysis (RDA) method was chosen to find out the most reasonable variation factors to explain the plant growth variation and Monte Carlo test method was used to examine the significance $(1,000$ times). Data statistical analysis and figures were done by Excel 2010 (Microsoft, Redmond, CA, USA) and Origin Pro 8 (OriginLab, Northampton, MA, USA).

\section{Results}

\subsection{Reed growth variation and soil heterogeneity among 100 plots}

Soil properties except $\mathrm{pH}$ varied largely among 100 plots (Table 1). Common reed performed a strong phenotypic plasticity and tissue water maintenance. The coefficient variation of plant characteristics except tissue water content was larger than $33 \%$, while that of tissue water content was lower than $19 \%$. The maximum of total salt $(31.47 \mathrm{~g} / \mathrm{kg})$ and the minimum of soil water content (SWC) indicated that natural common reed possessed high tolerance of water and salt stress.

\subsection{Correlation between plant growth variables and soil heterogeneity}

Plant growth variables (except WCs and $\mathrm{WCr}$ ) and deep soil $(>30 \mathrm{~cm})$ property factors performed significant correlations to some extent (Table 2). Soil water content was positively related to the common reed shoot quantity, coverage, shoot and rhizome dry biomass $(P<0.05$, Pearson correlation method). Soil salt content was negatively correlated to mean height, maximum height, shoot dry biomass and rhizome/shoot ratio $(P<0.01)$. Total nitrogen content only performed positive correlation with rhizome dry biomass. The available phosphorus content exhibited positive correlated with coverage and rhizome dry biomass $(P<0.01)$. The available potassium showed positive correlation to rhizome dry biomass and rhizome/shoot ratio $(P<0.01)$, and negative correlation to mean height, maximum height and shoot dry biomass $(P<0.05)$. The soil organic matter content showed significant correlations with coverage, shoot and rhizome dry biomass $(P<0.05)$. No significant correlations of tissue water content with soil property factors were found. 
Table 1 Statistic characteristics of common reed growth and soil heterogeneity

\begin{tabular}{|c|c|c|c|c|c|}
\hline \multirow[t]{2}{*}{ Index } & Mean & Min & Max & $\mathrm{SD}$ & Coefficient variation \\
\hline & \multicolumn{5}{|c|}{ Plant characteristics } \\
\hline Shoot quantity & 9.73 & 3 & 28 & 4.25 & 0.44 \\
\hline Mean height (cm) & 86.83 & 31 & 205 & 30.67 & 0.35 \\
\hline Maximum height $(\mathrm{cm})$ & 117.92 & 50 & 282 & 39.00 & 0.33 \\
\hline Coverage (\%) & 9.28 & 1 & 40 & 8.42 & 0.91 \\
\hline Shoot dry biomass (g) & 87.27 & 10 & 324.45 & 57.01 & 0.65 \\
\hline Rhizome dry biomass (g) & 391.43 & 23.90 & $1,028.20$ & 177.52 & 0.45 \\
\hline Rhizome/shoot ratio & 6.45 & 0.25 & 37.56 & 5.40 & 0.84 \\
\hline Shoot water content (\%) & 55 & 31 & 72 & 5.85 & 0.11 \\
\hline \multirow[t]{2}{*}{ Rhizome water content (\%) } & 49 & 16 & 91 & 9 & 0.19 \\
\hline & \multicolumn{5}{|c|}{ Soil property } \\
\hline SWC (\%) & 4.59 & 1.27 & 15.51 & 2.67 & 0.58 \\
\hline $\mathrm{pH}$ & 8.83 & 7.91 & 9.79 & 0.39 & 0.04 \\
\hline Total salt (g/kg) & 10.36 & 1.41 & 31.47 & 7.60 & 0.73 \\
\hline Organic matter (g/kg) & 2.63 & 1.04 & 5.41 & 0.94 & 0.36 \\
\hline Total nitrogen $(\mathrm{g} / \mathrm{kg})$ & 0.14 & 0.05 & 0.36 & 0.05 & 0.38 \\
\hline Available phosphorus (mg/kg) & 2.10 & 0.59 & 6.44 & 1.25 & 2.79 \\
\hline Available potassium (mg/kg) & 626 & 153 & 3,035 & 567 & 4.61 \\
\hline $\mathrm{CO}_{3}^{2-}$ content $(\mathrm{g} / \mathrm{kg})$ & 0.05 & 0.00 & 2.74 & 0.28 & 5.79 \\
\hline $\mathrm{HCO}_{3}{ }^{-}$content $(\mathrm{g} / \mathrm{kg})$ & 0.15 & 0.02 & 1.46 & 0.18 & 1.18 \\
\hline $\mathrm{Cl}^{-}$content $(\mathrm{g} / \mathrm{kg})$ & 4.21 & 0.42 & 15.08 & 3.56 & 0.84 \\
\hline $\mathrm{SO}_{4}^{2-}$ content $(\mathrm{g} / \mathrm{kg})$ & 1.76 & 0.11 & 9.44 & 1.64 & 0.93 \\
\hline $\mathrm{Ca}^{2+}$ content $(\mathrm{g} / \mathrm{kg})$ & 0.45 & 0.06 & 2.83 & 0.38 & 0.84 \\
\hline $\mathrm{Mg}^{2+}$ content $(\mathrm{g} / \mathrm{kg})$ & 0.19 & 0.00 & 1.42 & 0.21 & 1.15 \\
\hline $\mathrm{Na}^{+}$content $(\mathrm{g} / \mathrm{kg})$ & 2.72 & 0.04 & 9.74 & 2.22 & 0.82 \\
\hline $\mathrm{K}^{+}$content $(\mathrm{g} / \mathrm{kg})$ & 0.31 & 0.03 & 1.42 & 0.28 & 0.88 \\
\hline
\end{tabular}

Note: a, mean value of all soil layers which roots are encircled in, from depth 30 to $150 \mathrm{~cm}$.

Table 2 Correlation of plant growth variables and soil properties in deep soil layers (30-150 cm)

\begin{tabular}{ccccccccccc}
\hline & $\mathrm{Q}$ & $\mathrm{H}$ & $\mathrm{Hmax}$ & $\mathrm{C}$ & $\mathrm{DBs}$ & $\mathrm{WCs}$ & $\mathrm{WCr}$ & $\mathrm{DBr}$ \\
\hline SWC & $0.298^{* *}$ & -0.094 & -0.047 & $0.276^{* *}$ & $0.199^{*}$ & -0.146 & 0.020 & $0.206^{*}$ \\
pH & 0.115 & $-0.271^{* *}$ & $-0.346^{* *}$ & 0.173 & -0.178 & -0.065 & 0.074 & 0.190 \\
TDS & -0.102 & $-0.287^{* *}$ & $-0.290^{* *}$ & -0.147 & $-0.445^{* *}$ & -0.169 & -0.119 & 0.077 \\
OM & $0.201^{*}$ & -0.061 & 0.019 & 0.185 & 0.055 & -0.082 & 0.051 & $0.323^{* *}$ & 0.047 \\
TN & 0.177 & -0.125 & -0.027 & 0.153 & 0.057 & -0.046 & 0.116 & $0.216^{*}$ & -0.052 \\
AP & 0.127 & -0.051 & 0.008 & $0.321^{* *}$ & 0.095 & 0.025 & 0.124 & $0.378^{* *}$ & 0.144 \\
AK & 0.070 & $-0.283^{* *}$ & $-0.239^{*}$ & 0.118 & $-0.240^{*}$ & -0.047 & -0.039 & $0.380^{* *}$ & $0.568^{* *}$
\end{tabular}

Note: ${ }^{* *}$ and ${ }^{*}$ indicate the correlation is significant at 0.01 and 0.05 levels, respectively (Pearson correlation method, 2-tailed). Q, shoot quantity; H, Mean height; Hmax, maximum height; C, coverage; DBs, shoot dry biomass; DBr, rhizome dry biomass; WCs, shoot water content; WCr, rhizome water content; R/S, rhizome/shoot ratio; SWC, soil water content; TDS, total salt content; OM, soil organic matter; TN, total nitrogen concentration; AP, available phosphorus concentration; AK, available potassium concentration.

\subsection{The relationship between soil salt and shoot dry biomass}

As shown by the results of soil properties difference between surface and deep soils in Fig. 2, soil salt and ions contents in the shallow soil were mainly larger than those in the deep soil (values were mainly above the $\mathrm{X}$ axis). The $\mathrm{Cl}^{-}, \mathrm{SO}_{4}{ }^{2-}, \mathrm{Ca}^{2+}, \mathrm{Mg}^{2+}, \mathrm{Na}^{+}$and $\mathrm{K}^{+}$ were more shallowly distributed than $\mathrm{CO}_{3}{ }^{2-}$ and 

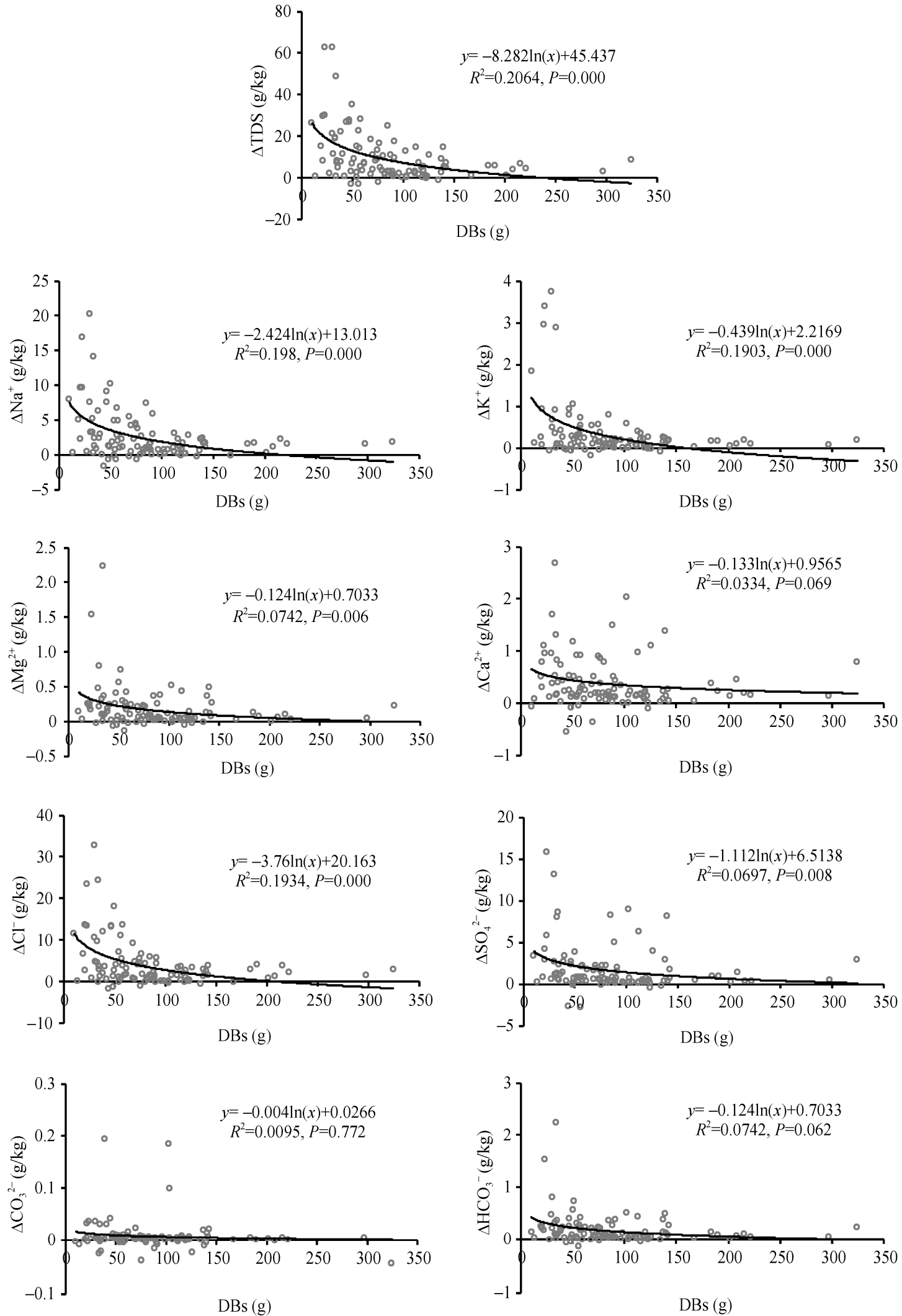

Fig. 2 Logarithm fitting of shoot biomass and soil differences between surface soil $(0-30 \mathrm{~cm})$ and deep soil $(30-150 \mathrm{~cm})$. DBs means shoot dry biomass. $\Delta$ means soil properties (TDS, $\mathrm{CO}_{3}{ }^{2-}, \mathrm{HCO}_{3}{ }^{-}, \mathrm{SO}_{4}{ }^{2-}, \mathrm{Cl}^{-}, \mathrm{Ca}^{2+}, \mathrm{Mg}^{2+}, \mathrm{Na}^{+}$and $\mathrm{K}^{+}$content) in shallow soil minus those in deep soil. 
$\mathrm{HCO}_{3}^{-}$. The logarithm fitting results of soil salt variation and shoot dry biomass showed that $\triangle \mathrm{TDS}$ were negative correlated to shoot dry biomass $\left(R^{2}=0.2106\right.$, $P=0.000$ ), suggesting an alleviation of salt uplifting by the cover of common reed. More detailed, this kind of alleviation for soil salt uplifting was mainly controlled by the ions of $\mathrm{Cl}^{-}\left(R^{2}=0.2027, P=0.000\right), \mathrm{SO}_{4}{ }^{2-}$ $\left(R^{2}=0.0697, P=0.008\right), \mathrm{Na}^{+}\left(R^{2}=0.2035, P=0.000\right), \mathrm{K}^{+}$ $\left(R^{2}=0.1902, P=0.000\right)$ and $\mathrm{Mg}^{2+}\left(R^{2}=0.0742, P=0.006\right)$. No significant correlations were found between shoot dry biomass and other soil ions.

\subsection{Determinants of reed colonization selected by RDA method}

As shown in Table 2, plant mean height, coverage, shoot biomass and rhizome/shoot ratio were more related to soil heterogeneity. These four variables were chosen as reed colonization data group, and RDA method was used to show soil heterogeneity explanation of colonization variance (Fig. 3). Soil variables totally explained $37.7 \%$ of the variance of colonization variables. The coverage of reed was mainly limited by soil water content and total nitrogen content. Mean height and rhizome/shoot ratio showed stronger correlation to total dissolved salt, while poorly correlated to soil water. Shoot biomass had negative correlation with soil salt and chlorine ion content.

In order to find out the main soil variables which

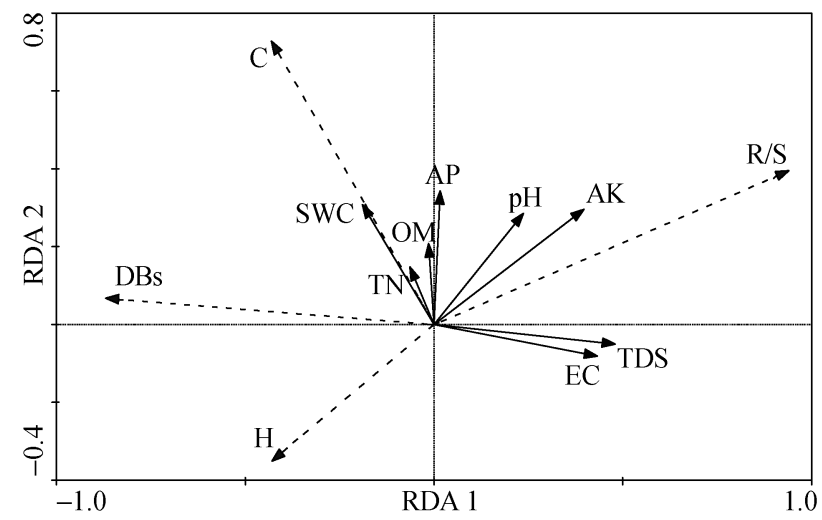

Fig. 3 Biplot of soil heterogeneity and reed colonization variables (RDA method). Dashed lines are plant growth variables, solid lines are soil heterogeneous factors. C, plant coverage. R/S, rhizome/shoot ratio. $\mathrm{H}$, mean height. DBs, dry biomass of shoot. SWC, soil water content. TDS, soil salt content. EC, electrical conductivity. TN, total nitrogen concentration. AP, available phosphorus concentration. AK, available potassium concentration. OM, organic matter content. limited common reed colonization, we use the Monte Carlo test (1,000 times) to examine the most related factors (Table 3). The results showed that soil salts (TDS, AK and EC) explained $34.6 \%$ of the common reed colonization variance (Table 3 ), followed by $\mathrm{pH}$ and soil water content. Common reed colonization was mainly limited by soil salt.

\section{Discussion}

\subsection{Common reed tolerance and correlation to soil heterogeneity}

Common reed showed high individual plastic differentials and tissue water content maintenance to soil heterogeneity which made common reed more tolerant to edaphic stresses. Our results indicated that common reed could survive in the soil with the mean water content low to $1.27 \%$ or the total dissolved salt content up to $31.47 \mathrm{~g} / \mathrm{kg}$. Undertaken by water and nutrient deficit, plants are prone to allocate less carbohydrate on shoot to balance the water and energy consumption, oppositely contribute more to roots (here rhizomes) for resource absorption (Clevering, 1998; Munns and Tester, 2008). The decreases of shoot coverage and biomass, and the increase of rhizome/shoot ratio were found in our study as well. It was proven that the underground system (roots and rhizomes) of plants might be greatly affected by edaphic stresses, such as extreme drought, high salt and poison ions contents, leading to tissue water content deficit (Munns, 2002; Zhu, 2002; Munns and Tester, 2008). However, field sampling results exhibited no significant correlations between tissue water content and soil variables in our study. Common reed had strong ability

Table 3 Results of soil variables by RDA method Monte Carlo test (1,000 times)

\begin{tabular}{ccccc}
\hline & Importance rank & Variance explained & $P$ value & $F$ value \\
\hline TDS & 1 & 0.130 & $<0.001$ & 14.696 \\
AK & 2 & 0.109 & $<0.001$ & 11.949 \\
EC & 3 & 0.107 & 0.003 & 11.747 \\
pH & 4 & 0.051 & 0.01 & 5.236 \\
SWC & 5 & 0.042 & 0.018 & 4.315 \\
AP & 6 & 0.027 & 0.057 & 2.737 \\
OM & 7 & 0.010 & 0.365 & 1.022 \\
TN & 8 & 0.008 & 0.455 & 0.800 \\
\hline
\end{tabular}


to maintain tissue water content which benefited for the survival and community succession of common reed in arid areas. Similar result was found by Elhaak et al. (1993).

Research had demonstrated that common reed growth was strictly limited by environmental factors, but the impacts of growth, fecundity and survival reduction varied across habitats (Budick, 2003). Our results also showed that soil heterogeneity had strong influence on natural reed growth. Soil water condition limited shoot quantity, relative coverage, shoot biomass and rhizome biomass, while salt stress constrained the height and shoot biomass of common reed. Plant height was mostly controlled by hydraulic limitations and mechanic constraints (Niklas, 2007). Uptake of water by roots was exactly limited by abiotic stresses, including soil salinity and water conditions (Aroca, 2012). Our results also exhibited negative correlations of the average and maximum of reed heights with soil salt-related factors, including $\mathrm{pH}$, electric conductivity, total salt, chlorine ion, calcium ion and sulfate ion contents, suggesting that soil salt affected the height of common reed.

Much research had revealed that soil nutrient heterogeneity exhibited impacts on plant growth status, physiology activity and ecological variation (Robinson, 1994; Hodge, 2004; Leishman and Thomson, 2005), which was also observed in our study. Significant correlation between soil nutrient and rhizome biomass of common reed was found. Available phosphorus had positive correlations with the aboveground module. However, available potassium had negative correlation with reed height and shoot biomass mainly owing to the high ion concentration and toxicity in this study area.

\subsection{Feedback of reed colonization to soil properties}

Common reed colonization got feedback on soil properties as well. Several studies have found that soil composition, elements and physical properties and biomes might be changed after the plant invasion and succession (Ehrenfeld, 2003; Reynolds et al., 2003; Ehrenfeld et al., 2005). Our results indicated that reed colonization had great influences on soil composition and ions movements. Soil organic matter mainly came from root turnover and root exudation (Matamala et al., 2003), the maintenance of coarse roots (here are the rhizomes) insistently producing fine roots made a continual increase of carbon in soil. A significant correlation of soil organic matter with shoot quantity and rhizome biomass of reed was found in our experiment, suggesting that soil organic matter would increase by the colonization of common reed.

Much research demonstrated the strong plant uplifting effects on soil ions and nutrients (Ehrenfeld, 2003; Jobbágy and Jackson, 2004; Turnbull, 2009), however, our results of soil salt difference between shallow and deep soils indicated that common reed colonization decreased the process of soil ion uplifting movements, thus alleviated the soil salinity process in arid areas. Salt concentration in subsoils in arid areas was mainly caused by high evaporation and poor precipitation for leaching (Yadav et al., 2011). Surface soil evaporation was negatively related to reed growth (Headley et al., 2012). Contrast to other species (Salsola ferganica and Halostachys caspica), the abandoned farmland growing reed had the weakest salt upper-accumulation (Zhu et al., 2013). Common reed colonization in arid areas might decrease the evaporation of surface soil thus hindered the water and salt uplifting from deep to shallow soil. Moreover, common reed had physiological function to restrict excessive $\mathrm{Na}^{+}$transporting to shoots (Matsushita and Matoh, 1991), thus alleviate the salt uplifting through plants.

\subsection{Soil determinants limiting reed colonization}

Environmental factors, such as nutrient, draught, salt and physical disturbance, straightly connected to the spread and succession of plants (Alpert et al., 2000; Meekins and McCarthy, 2001; Leishman and Thomson, 2005). Adverse environmental condition affects plant growth, reproduction and spread by water deficit, oxidative activity and ionic toxicity (Burdick, 2003; Munns and Tester, 2008). In our study, soil salt and water content explained much of the reed growth variation and they were the main factors limiting reed colonization.

Soil salts are the most limiting factors of reed colonization. High soil salts lead to less water uptake of root, and subsequently the water imbalance between shoot usage and root absorption leads to metabolic water deficit and oxidative activity (Munns, 2002; 
Munns and Tester, 2008; Aroca, 2012). The metabolic influences finally harm to plant survival, growth and reproduction (Budick and Konisky, 2003). Meanwhile, natural reed individuals were integrated together and shared resources through rhizomes (Hara et al., 1993), which may largely alleviate the impacts. It is possible that reed individuals in poor and dry soils share water and nutrient from other well-conditioned individuals through the connected rhizomes. Much evidence also supported that clonal physiological integration enhanced the abilities of resource access and escape from stresses (Bart and Hartman, 2000; Budick and Konisky, 2003). Moreover, the clonal rhizomes were usually succulent due to higher water retaining capability. The water retention of rhizome helped to alleviate the water deficit impairment during dry seasons. By these ways, natural reed was likely to be more sensitive to salt stress rather than water stress.

Soil nitrogen content was heterogeneous in these arid areas, but natural common reed didn't show much growth limitation or ecophysiological responses to soil nitrogen owing to its high tolerance of nitrogen deficit. Moreover, these responses might be covered up by the influences of water and salt stresses. Our results consist with the research by Zhao et al. (2013) in the Baiyangdian Lake, northern china, concluding that reed growth is more limited by water level variation than nutrient loadings.

\section{Conclusion}

The relations of common reed colonization and soil properties in arid areas of our study showed both similarity and differences to that in wet ones. Soil water deficit and salt stress were impressive in these areas, and common reed performed high tolerance of salt and water stress by strong phenotypic plasticity and tissue water content maintenance. The high soil available potassium concentration harmed to common reed growth rather than promotion in some of these areas. The edaphic factors most limiting common reed colonization here was soil salt rather than water and nutrients. Natural common reed performed to be less sensitive to soil water mainly because of the water sharing and storing mechanism by rhizomes. Soil nitrogen and phosphorus didn't show much growth limitation to natural common reed colonization. Inverse to soil ef- fects on natural reed, common reed got feedbacks to soil as well by the addition of soil organic matter and the alleviation of salt uplifting. Further study will pay more attention to both the goods and ills of common reed colonization process in these areas.

\section{Acknowledgements}

The research was supported by the Joint Funds of the National Natural Science Foundation of China (U1138303).

\section{References}

Alpert P, Bone E, Holzapfel C. 2000. Invasiveness, invasibility and the role of environmental stress in the spread of non-native plants. Perspectives in Plant Ecology, Evolution and Systematics, 3: 52-66.

Aroca R, Porcel R, Ruiz-Lozano J M. 2012. Regulation of root water uptake under abiotic stress conditions. Journal of Experimental Botany, 63: 43-57.

Baer S G, Blair J M, Collins S L, et al. 2004. Plant community responses to resource availability and heterogeneity during restoration. Oecologia, 139: 617-629.

Bardgett R D, Bowman W D, Kaufmann R, et al. 2005. A temporal approach to linking aboveground and belowground ecology. Trends in Ecology \& Evolution, 20: 634-641.

Bardgett R D, de Deyn G B, Ostle N J. 2009. Plant-soil interactions and the carbon cycle. Journal of Ecology, 97: 838-839.

Bart D, Hartman J M. 2000. Environmental determinants of Phragmites australis expansion in a New Jersey salt marsh: An experimental approach. Oikos, 89: 59-69.

Benoit L K, Askins R A. 1999. Impact of the spread of Phragmites on the distribution of birds in Connecticut tidal marshes. Wetlands, 19: 194-208.

Burdick D M, Konisky R A. 2003. Determinants of expansion for Phragmites australis, common reed, in natural and impacted coastal marshes. Estuaries, 26: 407-116.

Burke I C, Lauenroth W K, Riggle R, et al. 1999. Spatial variability of soil properties in the shortgrass steppe: the relative importance of topography, grazing, microsite, and plant species in controlling spatial patterns. Ecosystems, 2: 422-438.

Chambers R M, Osgood D T, Bart D J, et al. 2003. Phragmites australis invasion and expansion in tidal wetlands: Interactions among salinity, sulfide, and hydrology. Estuaries, 26: 398-406.

Clevering O A. 1998. An investigation into the effects of nitrogen on growth and morphology of stable and die-back populations of Phragmites australis. Aquatic Botany, 60: 11-25.

Collins B, Wein G. 1998. Soil heterogeneity effects on canopy structure and composition during early succession. Plant Ecology, 138: 217-217.

Elhaak M A, Sharaf el-din A, Shammour R H. 1993. Response of Phragmites australis to water stress from flooding to drought. Pakistan Journal of Botany, 25: 41-46.

Ehrenfeld J G. 2003. Effects of exotic plant invasions on soil nutrient cycling processes. Ecosystems, 6: 503-523 
Ehrenfeld J G, Ravit B, Elgersma K. 2005. Feedback in the plant-soil system. Annual Review of Environment and Resource, 30: 75-115.

Eppstein M J, Molofsky J. 2007. Invasiveness in plant communities with feedbacks. Ecology Letters, 10: 253-263.

Hara T, Van Der Toorn J, Mook J H. 1993. Growth dynamics and size structure of shoots of Phragmites australis, a clonal plant. Journal of Ecology, 81: 47-60.

Headley T R, Davison L, Huett D O, et al. 2012. Evapotranspiration from subsurface horizontal flow wetlands planted with Phragmites australis in sub-tropical Australia. Water Research, 46: 345-354.

Hodge A. 2004. The plastic plant: root responses to heterogeneous supplies of nutrients. New Phytologist, 162: 9-24.

Hook P B, Burke I C, Lauenroth W K. 1991. Heterogeneity of soil and plant $\mathrm{N}$ and $\mathrm{C}$ associated with individual plants and openings in North American shortgrass steppe. Plant and Soil, 138: 247-256.

Huston M A. 1993. Biological diversity, soils, and economics. Science, 262: 1676-1680.

Jobbágy E G, Jackson R B. 2004. The uplift of soil nutrients by plants: biogeochemical consequences across scales. Ecology, 85: 2380-2389.

Leishman M R, Thomson V P. 2005. Experimental evidence for the effects of additional water, nutrients and physical disturbance on invasive plants in low fertility Hawkesbury Sandstone soils, Sydney. Australia Journal of Ecology, 93: 38-49.

Lisamarie W, Richard G L. 1999. Effects of Phragmites australis (common reed) invasion on aboveground biomass and soil properties in brackish tidal marsh of the Mullica River. New Jersey. Estuaries, 22: 927-935.

Li X Y, Lin L S, Zhao Q, et al. 2010. Influence of groundwater depth on species composition and community structure in the transition zone of Cele oasis. Journal of Arid Land, 2: 235-242.

Majken P, Claudia B, Hans B. 2005. Tolerance and physiological responses of Phragmites australis to water deficit. Aquatic Botany, 81: 285-299.

Manning P, Morrison S A, Bonkowski M, et al. 2008. Nitrogen enrichment modifies plant community structure via changes to plant-soil feedback. Oecologia, 157: 661-673.

Marty V, Catherine G P, Michael J W. 2007. Biodiversity, exotic plant species, and herbivory: the good, the bad, and the ungulate. Forest Ecology and Management, 246: 66-72.

Matamala R, Gonzalez-Meler M A, Jastrow J D, et al. 2003. Impacts of fine root turnover on forest NPP and soil $\mathrm{C}$ sequestration potential. Science, 302: 1385-1387.

Matsushita N, Matoh T. 1991. Characterization of Na exclusion mechanisms of salt-tolerant reed plant in comparison with salt-sensitive rice plant. Physiologia Plantarum, 83: 170-176.

Meekins J F, McCarthy B C. 2001. Effect of environmental variation on the invasive success of a nonindigenous forest herb. Ecological Applications, 11: 1336-1348.

Meyerson L A, Saltonstal K, Windham L, et al. 2000. A comparison of Phragmites australis in freshwater and brackish marsh environments in North America. Wetlands Ecology and Management, 8: 89-103.
Munns R. 2002. Comparative physiology of salt and water stress. Plant, Cell and Environment, 25: 239-250.

Munns R, Tester M. 2008. Mechanisms of salinity tolerance. Annual Review of Plant Biology, 59: 651-681.

Niklas K J. 2007. Maximum plant height and the biophysical factors that limit it. Tree Physiology, 27: 433-440.

Qian Y B, Wu Z N, Yang Q, et al. 2007. Ground-surface conditions of sand-dust event occurrences in the southern Junggar Basin of Xinjiang, China. Journal of Arid Environments, 70: 49-62.

Reynolds H L, Packer A, Bever J D, et al. 2003. Grassroots ecology: plant-microbe-soil interactions as drivers of plant community structure and dynamics. Ecology, 84(9): 2281-2291.

Roberts J. 2000. Changes in Phragmites australis in south-eastern Australia: A habitat assessment. Folia Geobotanica, 35: 353-362.

Robertson G P, Crum J R, Ellis B G. 1993. The spatial variability of soil resources following long-term disturbance. Oecologia, 96: 451-456.

Robinson D. 1994. The responses of plants to non-uniform supplies of nutrients. New Phytologist, 127: 635-674.

Sonmez S, Buyuktas D, Okturen F, et al. 2008. Assessment of different soil to water ratios $(1: 1,1: 2.5,1: 5)$ in soil salinity studies. Geoderma, 144: 361-369.

Thevs N S, Gahlert Z F, Succow M M. 2007. Productivity of reed (Phragmites australis Trin. ex Steud.) in continental-arid NW China in relation to soil, groundwater, and land-use. Journal of Applied Botany and Food Quality, 81: 62-68.

Tilman D, Wedin D. 1991. Plant traits and resource reduction for five grasses growing on a nitrogen gradient. Ecology, 72: 685-700.

Turnbull L C. 2009. Changes to nutrient and carbon cycling, soil properties, and ecosystem processes by the invasive plants Phalaris arundinacea and Zostera japonica. PhD Dissertation. Eugene: University of Oregon.

Valerie T E, Christine V H. 2008. Embracing variability in the application of plant-soil interactions to the restoration of communities and ecosystems. Restoration Ecology, 16: 713-729.

Vasquez E A, Glenn E P, Brown J J, et al. 2005. Salt tolerance underlies the cryptic invasion of North American salt marshes by an introduced haplotype of the common reed Phragmites australis (Poaceae). Marine Ecology Progress Series, 298: 1-8.

Vinton M A, Burke I C. 1995. Interactions between individual plant species and soil nutrient status in short-grass steppe. Ecology, 76: 1116-1133.

Weis J S, Weis P. 2003. Is the invasion of the common reed, Phragmites australis, into tidal marshes of the eastern US an ecological disaster? Marine Pollution Bulletin, 46: 816-820.

Yadav S, Irfan M, Ahmad A, et al. 2011. Causes of salinity and plant manifestations to salt stress: a review. Journal of Environmental Biology, 32: 667-685.

Zhao Y, Xia X H, Yang Z F. 2013. Growth and nutrient accumulation of Phragmites australis in relation to water level variation and nutrient loadings in a shallow lake. Journal of Environmental Sciences, 25: $16-25$.

Zhu H W, Xia J, Cao G D, et al. 2013. Dynamic change of soil salinity in salinization abandoned farmland and affecting factors. Soils, 45: 339-345.

Zhu J K. 2002. Salt and drought stress signal transduction in plants. Annual Review of Plant Biology, 53: 247-273. 